\title{
Career Interruptions: How Do They Impact Pension Rights?
}

\author{
Najat El Mekkaoui de Freitas ${ }^{\mathrm{a}}$, Cindy Duc ${ }^{\mathrm{b}}$, Karine Briard ${ }^{\mathrm{c}}$, \\ Sabine Mage ${ }^{\mathrm{d}}$ and Bérangère Legendre ${ }^{\mathrm{e}}$ \\ ${ }^{a}$ University Paris-Dauphine, Place du marechal de lattre de tassigny, Paris 75016, France. LEDa, \\ UMR225-DIAL. \\ ${ }^{\mathrm{b}}$ University Paris-Dauphine, Paris. \\ ${ }^{\mathrm{c}} \mathrm{CNAV}$, Paris. \\ ${ }^{\mathrm{d}}$ University Paris-Dauphine, Paris, LEDa, IRD, UMR225-DIAL. \\ ${ }^{\mathrm{e}}$ University Paris-Dauphine, Paris and University d'Orléans, LEO, UMR6221.
}

The aim of this article is to analyse the question of career interruptions and to evaluate their impact on pension retirement for French private sector workers. Using the last French survey on households' wealth (2003-2004), we first study the career set-backs for individuals born between 1937 and 1949. We highlight the new trends in professional paths. The risk of unemployment and job flexibility has sharply risen. As a consequence, some cohorts appear to be more exposed to career interruptions. Second, we determine how pension rights for French employees are affected by different career accidents. We consider unemployment, part-time employment and inactivity periods. Our results show how, by compensating for some career accidents, the French legislation allows individuals to receive, in some cases, the same level of social security pension that they would have received with a smooth professional path.

The Geneva Papers (2011) 36, 440-457. doi:10.1057/gpp.2011.12

Keywords: career interruption; pensions; social security

\section{Introduction}

The retirement age and the standard of living of pensioners depend on a variety of individual and familial life routes: age of employment entry, children, life expectancy, unemployment, inactivity, etc. These deviations from a continuous career are more frequent than in the past in most OECD countries and could induce a strong impact on the age of retirement and on pension benefits. ${ }^{1}$ The aim of this article is to evaluate the effects of several cases of career breaks on the retirement pension for French workers.

The literature dealing with this subject highlights the specific situation of women. A lot of studies provide an analysis of women's career interruptions due to childbirth. Arun et $a .^{2}$ and Malo and Munoz-Bullon ${ }^{3}$ conduct this type of study respectively in the Australian and British cases. According to Arun et al., ${ }^{2}$

\footnotetext{
${ }^{1}$ COR (2007).

2 Arun et al. (2004).

${ }^{3}$ Malo and Munoz-Bullon (2008).
} 
women face income penalties because of their child-related career breaks. Malo and Munoz-Bullon $^{3}$ show that women tend to choose lower-prestige occupations in anticipation of their career interruptions. Nakamura and $\mathrm{Ueda}^{4}$ investigate the determinants of career interruption following childbirth for married women in Japan. Their results show the difficulty for an educated woman to find an equivalent position when she quits her job due to childbirth. From Danish data, Gupta and Smith $^{5}$ assess the negative impact of children on mothers' human capital accumulation. In most cases, the number of children has a negative effect on women's wages and consequently on women's pensions.

While children affect particularly women's careers, others career break determinants could be identified. The literature on the French case ${ }^{6-10}$ shows that many individuals are now affected by several breaks during their professional trajectory due to unemployment, early retirement, part-time work or inactivity.

Little research has been done to estimate the impact of these interruptions on pension benefits.

We provide an analysis of the consequences of career accidents on pension retirement in the case of French employees. Their situations are quite relevant because, firstly, the last pension reforms (2003-2010) have introduced new rules on pension rights. Secondly, in France, workers acquire pension rights in some cases of career interruptions. Indeed, French legislation allows compensation for unemployment, illness or invalidity periods in terms of duration, but the amount of pension wages is often calculated from a smaller reference wage. Inactivity could be also compensated by allowing insurance periods but only in the case of children's education.

This article distinguishes two sets of analysis. On the one hand, this paper investigates the recent evolution of career accidents from microdata provided by a French survey. Our results indicate that workers and pensioners are experiencing very different economic situations. These disparities are strengthened by taking into account the generation, the gender or the socio-economic group. On the other hand, this paper investigates the impact of different career accidents (unemployment, parttime work, etc.) on pensions.

The plan of the article is as follows. The next section provides a survey of the recent literature on the evolution of the French professional trajectories. The subsequent section describes the methodology of career reconstruction and presents career path analysis. The penultimate section assesses the impact of career accidents on pensions. The final section concludes.

\footnotetext{
${ }^{4}$ Nakamura and Ueda (1999).

${ }^{5}$ Gupta and Smith (2002).

${ }^{6}$ Caussat (1996).

${ }^{7}$ Cloarec (2000).

${ }^{8}$ Colin et al. (2000).

${ }^{9}$ Briard (2007).

${ }^{10}$ El Mekkaoui de Freitas et al. (2008).
} 


\section{A brief literature review}

The recent literature on career interruptions indicates that smooth careers are not frequent. This phenomenon is particularly observed in France over the last years. Many French studies have devoted their attention to these increasing career breaks. ${ }^{7,8,11,12}$ Cloarec $^{7}$ focuses on the transition time between the last working period and retirement. The author shows that today the breaks are more frequent at the end of career than in the past. Precisely, the results indicate that the time between the end of working life and the beginning of retirement increased from less than one year for people born before 1912, to 2.5 years for people born between 1932 and 1936 .

By using the same survey, Burricand and Roth ${ }^{11}$ pointed towards the crucial role of French legislation, namely the possibility for workers in the private sector to retire earlier. ${ }^{13}$ However Bommier et al. ${ }^{12}$ indicate that the activity rate ${ }^{14}$ remains stable for years. According to these authors, part-time work has developed over the last years for men and women. From data provided by the French Employment survey, they indicate that this phenomenon is observed more frequently for men aged from 55 to 59: between 1984 and 1997, the proportion of individuals concerned by part-time employment has tripled.

Magnac et al. ${ }^{15}$ carry out a study on the end of careers. They examine the impact of an unemployment period, at the end of professional life, on retirement age. They take into account the effects of the last French reform in 2003 which increased the duration of contributions to receive a full pension.

Using a survey on retirees' incomes, ${ }^{16}$ wages data, ${ }^{17}$ data on unemployment benefits and early retirement, ${ }^{18}$ they study accumulated pension rights as well as career and retirement decisions. Their analysis shows that women retire later than men, as they experience more career interruptions.

With a duration model, they analyse the impact of unemployment on retirement decisions. According to their results, workers have a higher probability to retire at the ages of 60 and 65 if they experienced an unemployment period during their career.

Colin and Mette ${ }^{19}$ focus their research on the impact of career set-backs on pension amounts for workers from the private sector by taking into account the 1993 French reform. They observed that both the break in the working career and the duration of working life have an impact on pension benefits. However, the evolution of the legislation shows that different generations are not submitted to the same treatment.

${ }^{11}$ Burricand and Roth (2000).

${ }^{12}$ Bommier et al. (2003).

131992 French agreement.

14 According to ILO.

15 Magnac et al. (2006).

${ }^{16}$ Data from the Échantillon Interrégimes des Retraités (EIR), a panel which gives information about a retiree's pension in all pension schemes (private-régime general-public pension schemes and complementary schemes).

${ }^{17}$ Annual wage returns data given by firms (DADS).

${ }^{18}$ Data about the unemployment benefits and pre-retirement from the Union Nationale pour l'Emploi dans l'Industrie et le Commerce (UNEDIC).

${ }^{19}$ Colin and Mette (2003). 
Cohorts fully concerned by the reform of 1993 benefit from a lower replacement rate. Workers experiencing a set-back such as unemployment, part-time employment or inactivity often receive a lower replacement rate. This impact can be considerable in terms of pension amounts.

In our article, we follow the same methodology used by Colin and Mette. Nevertheless, we also evaluate the impact of multiple career breaks on retirement pensions in the French case. Before evaluating the impact of career interruptions, we have to build the career path.

\section{Methodology of career reconstruction and career path analysis}

\section{Data and methodology}

In order to reassemble the careers of individuals belonging to the 1937-1949 generations, the information given by the INSEE "Enquête Patrimoine" 2003-2004 is very helpful to conduct an analysis by cohort as well as by gender. The Patrimoine survey 2003-2004, including 9,692 households and 22,821 individuals (48 per cent men and 52 per cent women) aged 0-99 years old, was completed by INSEE between October 2003 and January 2004 and contains data on the entire metropolitan area. The objective was to evaluate the ownership and the value of different types of capital assets or liabilities, to describe the professional capital of self-employed workers to retrace the history (both conjugal and professional) behind the capital of the households (inheritance, professional activity cycle). It is the last survey available on this subject. It follows the survey on Financial Assets in 1992 and the Patrimoine survey in 1998.

The survey includes four questionnaires completed by French households and individuals: the individual part, the households' behaviours, the 'Product' which provides information on the savings and financial products as well as the capital holdings of the household and the 'Transmission' which refers to the different transfers of capital between ancestors and descendants.

This survey particularly informs the reader of the financial and non-financial assets of the household belonging to the selected individual questioned, their revenue, their age, their socioprofessional category, their education/training, their marital situation and their status (active, inactive, retired). Furthermore, the survey also includes the type (and sometimes the amount) of asset detention retained by the household (checking account, savings account, real estate, life insurance, corporate savings, etc.). Retirement pensions, both State and private (type and amount), are also presented.

In addition, the survey reports on the situation of households faced with unemployment, illness and financial constraints. Individuals are asked about their career, their different occupations over their past professional path and their unemployment, part-time employment or inactivity periods. $^{20}$

${ }^{20}$ Another French survey, "Echantillon Interrégimes des Cotisants (EIC)", regularly informs about the pension rights accumulated by the insured in different public pension schemes. However, we prefer the Patrimoine survey because it allows us to combine the personal behaviours of the individuals with their 
The role of gender is also analysed in detail using the Patrimoine survey. This survey is particularly useful, as it encompasses a retrospective calendar of the individuals' professional careers. Moreover, the database offers information about all pension schemes. The family characteristics are also provided (number of children). ${ }^{21}$ Starting with the initial situation of each individual, this calendar allows the reader to progressively trace the professional careers of the individual and to identify any interruptions in activity that may have taken place (unemployment and inactivity). The length of each employment can be found, even if the calendar depends on the memory of the surveyed individual. Indeed, some career set-backs may not be mentioned, either because the period was too short for the individual to remember, or because the period of unemployment or inactivity was perceived as a painful phase and therefore difficult to bring up. In other words, the survey minimises the number and the length of career set-backs.

Initially, the surveyed individuals had the choice between 15 modalities. Given the complexity and the multitude of professional careers, a regrouping of the different occupations into seven categories was established in the following manner:

\begin{tabular}{ll}
\hline Category & Grouping \\
\hline 1 & Study/Training/Apprenticeship/National Service \\
2 & Private sector \\
3 & Public sector \\
4 & Self-employed/Entrepreneur/Working in the spouse's company \\
5 & Unemployed (short and long term)/Searching for employment \\
6 & Retire/Early retirement/Out of business \\
7 & Inactive/Housewife/In search or not of employment \\
\hline
\end{tabular}

Source: Categories produced by the authors based on the Patrimoine Survey 2003-2004, INSEE.

For each cohort, an analysis of the individuals' careers was performed, starting with their initial occupation and followed by a decomposition of their different occupational movements.

\section{Career path analysis}

Tables 1 and 2 present the prominent results obtained for the men and women belonging to the 1937-1949 generations.

The results indicate that career set-backs are becoming more frequent, particularly for people born after 1944; this is the case for women as much as for men.

As time passes by, men experiencing careers without set-backs before the age of 55 are rarer compared with the generation 1937-1939 (Table 1). These men represented 89 per cent of the 1937-1939 generations and less than 80 per cent of the 1942-1944 generations.

household's characteristics, something we cannot do using the EIC. Indeed, we cannot neglect the family phenomena when studying retirement planning.

${ }^{21}$ In the survey "Echantillon Interrégimes des Cotisants" (EIC), children and unemployment without benefits are not recorded. 
Table 1 Evolution of career set-backs for men before they are 55 years old

\begin{tabular}{|c|c|c|c|}
\hline Generation & $1937-1939$ & $1942-1944$ & $1947-1949$ \\
\hline Per cent of individuals without any career set-backs at 55 years old & 89.1 & 79.3 & 82.0 \\
\hline Among them, without changes & $32 \%$ & $35 \%$ & $39.0 \%$ \\
\hline $\begin{array}{l}\text { Per cent of individuals having known at least one period of } \\
\text { unemployment }\end{array}$ & 5.9 & 15.9 & 12.6 \\
\hline Among them, per cent of individuals having known: & & & \\
\hline - unemployment in the beginning/middle of their career & 26 & 60 & 50 \\
\hline —unemployment at the end of career & 74 & 40 & 50 \\
\hline Multiple periods of unemployment & $1 \%$ & $2 \%$ & $3.1 \%$ \\
\hline $\begin{array}{l}\text { Per cent of individuals having known at least on period of inactivity } \\
\text { Among them, per cent of individuals having known: }\end{array}$ & 4.70 & 7.6 & 7.3 \\
\hline —inactivity in the beginning/middle of their career & 60 & 44 & 50 \\
\hline —inactivity at the end of career & 40 & 66 & 50 \\
\hline Multiple periods of inactivity & $0.3 \%$ & $0.6 \%$ & $1.1 \%$ \\
\hline $\begin{array}{l}\text { Per cent of individuals having known one or more periods of } \\
\text { unemployment and inactivity }\end{array}$ & 0.3 & 2.7 & 2.0 \\
\hline Number of observations & 321 & 328 & 451 \\
\hline
\end{tabular}

Source: Patrimoine Survey 2003-2004, authors' calculations.

Table 2 Evolution of career set-backs for women before they are 55 years old

\begin{tabular}{|c|c|c|c|}
\hline Generation & $1937-1939$ & $1942-1944$ & $1947-1949$ \\
\hline \multirow{2}{*}{$\begin{array}{l}\text { Per cent of individuals without any career set-backs at } 55 \text { years old } \\
\text { Among them, without changes }\end{array}$} & 38.9 & 40.9 & 44.9 \\
\hline & $51.5 \%$ & $48.9 \%$ & $51.9 \%$ \\
\hline $\begin{array}{l}\text { Per cent of individuals having known at least one period of } \\
\text { unemployment }\end{array}$ & 12.8 & 18.1 & 15.6 \\
\hline \multicolumn{4}{|l|}{ Among them, per cent of individuals having known: } \\
\hline — unemployment in the beginning/middle of their career & 52 & 34 & 49 \\
\hline —unemployment at the end of career & 48 & 66 & 51 \\
\hline Multiple periods of unemployment & $2.3 \%$ & $2.3 \%$ & $3.0 \%$ \\
\hline $\begin{array}{l}\text { Per cent of individuals having known at least on period of inactivity } \\
\text { Among them, per cent of individuals having known: }\end{array}$ & $55.7 \%$ & $34.5 \%$ & $47.5 \%$ \\
\hline —inactivity in the beginning/middle of their career & 61 & 69 & 65 \\
\hline —inactivity at the end of career & 39 & 31 & 35 \\
\hline Multiple periods of inactivity & $14.2 \%$ & $10.5 \%$ & $7.8 \%$ \\
\hline $\begin{array}{l}\text { Per cent of individuals having known one or more periods of } \\
\text { unemployment and inactivity }\end{array}$ & 7.3 & 8.8 & 8.0 \\
\hline Number of observations & 345 & 354 & 463 \\
\hline
\end{tabular}

Source: Patrimoine Survey 2003-2004, authors' calculations.

Increasing periods of unemployment and inactivity are also observed. More and more men are experiencing at least one period of unemployment during their career path (6 per cent for the 1937-1939 generations, 16 per cent for the 1942-1944 generation and 13 per cent for the 1947-1949 generations).

Inactivity periods are also more and more frequent. 
Very few men from the 1937-1939 generation declared having known multiple unemployment periods, while 2 per cent and more than 3 per cent of the men from the 1942-1944 and the 1947-1949 generations respectively claimed having been inactive multiple times throughout their professional career.

For women, a decrease in the periods of inactivity (Table 2) was observed. Fewer and fewer women experience multiple periods of inactivity during their career. As a result, women from more recent generations are more present on the labour market and therefore experience more unemployment periods than their elders (18 per cent for the 1942-1944 generations, 16 per cent for the 1947-1949 generations, vs. 13 per cent for the 1937-1939 generation).

The career path of a woman appears to be less and less perturbed over time. A career without any interruptions is observed for 39 per cent of the women from the 1937-1939 generations, 41 per cent from the 1942-1944 generations and 45 per cent from the 1947-1949 generations.

\section{Impact of career accidents on pensions}

In this part, we propose to assess the impact of fluctuations around the standard career path on the pension amount and the replacement rate, which is the simplest and most used indicator of the link between pensions and wages. To do that, we use the sample cases method and define sample cases of a private sector worker's career path which deviates from a full-time continuous career because of unemployment, part-time work or inactivity.

We limit our study to people who receive a pension from the old age fund of the French Social Security, called CNAV (Caisse nationale d'assurance vieillesse). However, we assess the total amount of the pension determined at retirement, which includes the complementary pensions of ARRCO and AGIRC (only white collar workers).

\section{Definitions and sample cases}

"Sample cases" or "typical cases" are often used for the assessment of public policies. They refer to units like individuals or households, whose characteristics are entirely specified for the study carried out. With regard to existing situations, which would be extracted from a population, sample cases have the advantage of being simple and not being soiled by disruptive singular attributes.

For the study of pension rights, the sample case can represent an insured individual or even a couple or a household if the analysis is extended to survivors' benefits. This sample of insured is then characterised by the attributes examined by the pension scheme for the calculation of one's pension rights: year of birth, sex, number of children, wages, etc.

The sample case can be typical or atypical, representative and/or illustrative. If the goal of the study is to approach a description of reality, sample cases are generally chosen as representative of the most frequent individual situations. This method collides with the problem that an average situation is not always representative of all the individual situations which it is supposed to describe. Nevertheless, new 
developments based on the classification of longitudinal professional courses allow us to identify weighted typical cases from a whole population. ${ }^{9}$

If the goal of the sample cases is simply to illustrate the consequences of the pension's calculation rules, the sample cases can be fictitious, only illustrative, without a narrow link to the characteristics of the population. The stylised sample cases used in this paper, partly built on statistics, can be assigned to an intermediate approach, between representative and conventional cases.

The reference case that we consider is the path of a childless individual who begins to work at the age of 20 and stops at 60 after a continuous career without breaks or reduced activity periods. It corresponds to the norm on which the calculation of the pension paid by the social security plan is based (see Appendix).

Five deviations around this reference case are considered: ${ }^{22}$

- a part-time job, between the ages of 30 and 44;

- an unemployment period spread over the career path: two years between the $9^{\text {th }}$ and the $11^{\text {th }}$ year of the working life, two years between the $19^{\text {th }}$ and the $21^{\text {st }}$, one year between the $29^{\text {th }}$ and the $30^{\text {th }}$;

- five years of early retirement, which can be assimilated to five years of unemployment at the end of the active life;

- an inactivity period between 35 and 39 years to raise two children, associated to "old age insurance for parents living at home" (OIPH, see Appendix);

- an inactivity period between 35 and 39 years to raise two children, but not associated to OIPH.

Except these last two sample cases supposed to be those of women with two children, cases indifferently characterise a childless woman or a man.

In addition to Colin and Mette, ${ }^{19}$ our analysis also takes into account professional paths with both unemployment and inactivity. We specify three durations for the unemployment spells, one year, three years and five years, and two durations of inactivity, three years and five years. The place of these events on the career is the following:

- one year of unemployment at the age of $39\left(20^{\text {th }}\right.$ year of the working life);

- three years of unemployment: one at the age of 29, two years at the ages of 38 and 40;

- five years of unemployment: same spreadout as the second sample case;

- three years of inactivity from the ages of 31 to 33 years;

- five years of inactivity from the ages of 31 to 35 years.

The professional paths with five years of inactivity are supposed to be followed by women with two children.

Three earnings profiles are considered:

- the flat profile of a blue collar worker earning 1.2 times the Guaranteed Minimum Wage (GMW);

\footnotetext{
${ }^{22}$ These five cases are those of Colin and Mette (2003). They are convergent with the observations made on the Patrimoine survey (El Mekkaoui et al., 2008).
} 
- the growing profile of a blue collar worker which starts at 0.5 times the social security wage ceiling (SSWC) ${ }^{23}$ and finishes at one SSWC after 40 years of activity;

- the growing profile of a white collar worker (with contribution to AGIRC) which starts at one SSWC and finishes at two SSWC.

To simplify, we assume that the earnings progress is linear and not concave as it is generally observed. In all cases, after the interruption of activity, the wage is the same as in the absence of interruption. For the projection, the GMW and the SSWC are supposed to grow at an annual rhythm of 1.7 per cent until 2010 and 1.8 per cent beyond (except inflation). The rate of payroll contributions is constant in the projections. The retirement age is supposed to remain at 65 , so that the pensions are always computed at the full rate, without penalties.

\section{Results and analysis}

At retirement, former employees of the private sector receive at least two pensions from the statutory plans: the pension benefit of the social security, which is a function of the insurance period and the best wages, and the pension of the complementary plans, ARRCO and AGIRC for white collar workers, which are proportional to contributions. Yet, each of these schemes includes some compensation mechanisms so that an "accident" in the career path is generally smoothed.

\section{Impact on the social security pension paid by $C N A V$}

For the 1940 generation, part-time employment, unemployment and inactivity, associated or not with the OIPH taking one by one causes a maximum loss of 12.8 per cent on the CNAV pension amount (Table A1).

The impact of an accident on the insurance period is limited by various mechanisms included in the legislation (see Table 3).

The insurance period is of 160 quarters for the sample case with part-time employment because the annual wage is supposed to be always higher than $800 \mathrm{~h}$ of GMW. For the case with unemployment periods, wages earned during years without unemployment are sufficient to validate four quarters a year too; moreover, the years for which the unemployment period lasts all year are completely compensated with the validation of four assimilated periods (AP). We observe the same result for the cases with an early retirement or an inactivity period associated to OIPH. The only cases in which the insurance period is less than that of the continuous career are the sample cases with inactivity and no OIPH. Of course, losses in the insurance period are less when a bonus is granted for children (16 quarters for two children). For example, the insurance period of the case with five years of unemployment and three years of inactivity is only 148 quarters, while it is 156 for the case of five years of unemployment and five years of inactivity with two children (Table A1).

\footnotetext{
${ }^{23}$ The social security ceiling is the maximal wage submitted to contribution for the basic pension scheme. It is indexed on wages' growth. On 1 January 2010, the annual ceiling was $€ 34,620$.
} 
Table 3 Taking the career accidents into account in the pension of the private sector employees

\begin{tabular}{ll}
\hline Career accident & $\begin{array}{l}\text { Pension benefit compensation, first pillar } \\
\text { (CNAV) }\end{array}$ \\
\hline $\begin{array}{l}\text { Unemployment } \\
\text { periods }\end{array}$ & $\begin{array}{l}\text { CNAV compensates unemployment in terms of } \\
\text { insurance period by granting one quarter for } \\
50 \text { days of allowances. If the unemployment } \\
\text { period is not compensated by the unemployment } \\
\text { fund, it is taken into account by the pension } \\
\text { scheme within the limits of four quarters } \\
\text { (continuous period or not) and, from the second } \\
\text { period, on the condition of succeeding to a } \\
\text { compensated unemployment period. }\end{array}$
\end{tabular}

Inactivity Inactivity periods are compensated only in the periods case of parental leave: a rise of the insurance period is granted to men and women, but they cannot cumulate it with the insurance period bonus of eight quarters per child, which is automatically granted to women. ${ }^{\text {b Low-income }}$ and children's age conditions (one child under 3 years of age or three children under 21 ), reduced activity or inactivity periods can also give the right to the pension of the "old age insurance for parents living at home" (OIPH), which consists in granting wages (based on GMW) and quarters. These familial rights are granted without the obligation of stopping activity, and they are cumulative.

Part-time and

\section{A quarter is validated from $200 \mathrm{~h}$ of the} Guaranteed Minimum Wage (GMW), that is to say four quarters for a half-time at the GMW all year long or a full-time at the GMW for six months. The important number of wages counted for the AAW penalizes the insured with short and $\backslash$ or intermittent career paths. Since 2004, when no quarter is validated, the corresponding year is excluded. However, if a single quarter is validated, the wage - though lower-is considered an annual wage.

\author{
Complementary schemes compensation \\ ( $A R R C O$ and $A G I R C$ )
}

The unemployment periods allow the granting of points on the basis of the last wages: the daily wage determines the amount of unemployment allowances for ARRCO and the three last years define allowances for AGIRC

Periods of inactivity give points during parental leave if contributions are paid (with the agreement of the employer), but there is no OIPH. In general, there is no compensation for the interruption of working life due to the children's education, but a pension bonus is given to parents of three or more children.

Periods of weak payments are not compensated because the points to which the workers are entitled are proportionate to their contributions. Since 2005 , people have the possibility of paying the contribution on the basis of full-time employment, but in accordance with their employers.

\footnotetext{
${ }^{a}$ Consequently, periods of unemployment are quite well compensated by basic and complementary plans. However, the pension of an insured person having known unemployment periods could be lower than if he had followed a continuous career path if:
}

- more than one year of unemployment isn't compensated by the unemployment fund;

- the number of days of the unemployment period was lower than 50 in a calendar year;

- wages earned during the years where he was unemployed are included in the annual average wage (AAW); this is often the case if the working life is shorter than 25 years.

\footnotetext{
${ }^{b}$ The bonus of eight quarters by child was reformed in 2010. Now, four out of eight quarters can be given by the father according to the decision of the parents.
}

Whatever the sample case, the wages are superior or equal to $1.2 \mathrm{GMW}$ so that the pension is not raised at the contributory minimum and the annual average wage (AAW) is effectively taken into account for the calculation of the pension. As a consequence, the incidence of a non-salaried period is variable according to its position in the career timeframe and the wages profile: if it concerns a period of weak (respectively high) earnings, AAW - and consequently the pension benefit—will 
be equal (respectively lesser) than for a continuous career path. Thus, a period of unemployment generally affects AAW and pension benefits less than an early retirement period which is situated at the end of active life. For the sample cases studied, early retirement causes a decline reaching about 13 per cent for a career path with wages growing from 0.5 to one SSWC, 6 per cent for a flat profile with wages at 1.2 GMW and 5 per cent for wages going up to the ceiling (Table 3), while these values are always less in case of an unemployment period with the same duration: respectively $-2.1,-1.0$ and -0.4 per cent.

Besides, in case of an accident (part-time, unemployment or inactivity), the selection of the highest wages limits the decline of the AAW and, as a consequence, the pension. For example, for a career paid 1.2 GMW, the period of part-time employment induces a loss of 18.5 per cent of the career average wage for the 1940 generation, but AAW being calculated on only the best wages (the 17 highest ones), its decline remains weak ( 0.4 per cent, Table A1). The "shock absorber" role of the calculation rule of the AAW is also particularly visible on the case mixing unemployment and inactivity breaks (Table A1). In particular, when we consider 10 years without wages, that is one quarter of the total career duration, the AAW only declines 0.4 per cent in the sample case with the higher wages ( 1 to $2 \mathrm{SSW}$ ) when the career average wage declines about 4 per cent.

For the more recent generations, the increasing number of wages included in the AAW (from 10 to 25 enacted in 1993 reform) leads to a decline of the ratio AAW/ career average wage (Table A1). This weakens the "shock absorber" mechanism, particularly for the increasing proportion of people for whom the working life is shorter than the number of years of wages considered in AAW. The risk of a decrease in pensions is strengthened by the gradual increase in the insurance period required to benefit from a full pension (from 150 to 164 quarters enacted by the 1993 and 2003 reforms) and to have a complete pension (2003 reform). As a consequence, the standard career of 40 years becomes incomplete and does not represent the norm for future generations. The relative losses due to a deviation from the new standard career could also increase.

\section{Impact on the total amount of the pension}

The complementary plans are often qualified as more contributive than the basic plan because they do not include implicit redistributive mechanisms such as the AAW calculation rules. Nevertheless, they compensate some accidents like unemployment periods to a wider extent by granting as many points as the wage was maintained, ${ }^{24}$ while the basic plan validates quarters but does not record wages, which can have a negative impact on the AAW.

Evidence of redistributive mechanisms in the pension calculation rules, specifically in the basic pension, is given by decreasing replacement rates: the higher the wages during the working life, the stronger the erosion in purchasing power at retirement. In the sample cases under consideration, redistribution essentially plays between the low

\footnotetext{
${ }^{24}$ This rule was abrogated in 2001. Indeed, the new legislation for unemployment period is now contributive.
} 

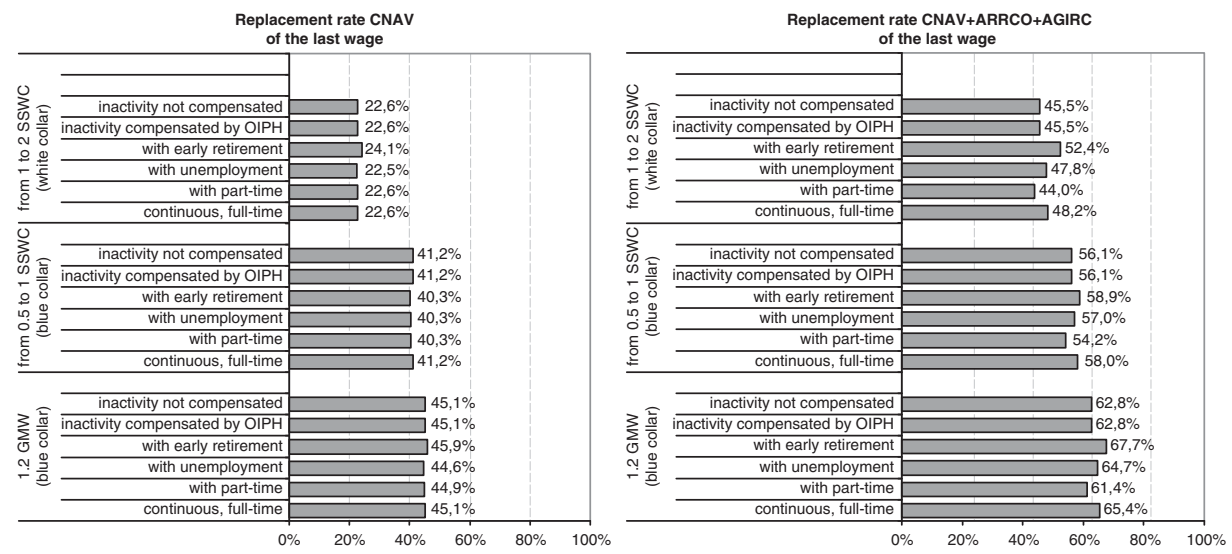

Figure 1. Gross replacement rate of the last wage (retirement at 65 years).

*Analysis on sample cases with only one kind of accident-1940-generation.

* For the case with early retirement, the last wage is the wage earned at 54 years and not at 59 .

or the average level of earnings (1.2 GMW or 0.5 to $1 \mathrm{SSCW})$ and the high level of earnings (1 to $2 \mathrm{SSCW}$ ), regardless of the replacement rates computed on the last wage (see Figure 1) or on the average wage (see Table A1).

The total effect of a deviation from the standard career path on the total amount of pension depends on the nature of the deviation.

The differences in wages - due to part-time employment, for example-are not smoothened in the complementary pensions. As expected, with regard to other accidents, the insured who have part-time employment periods are those who lose most in terms of complementary pension: the loss reaches 18.7 per cent for the career at $1.2 \mathrm{GMW}, 17.54$ per cent for the career growing from 0.5 to $1 \mathrm{SSWC}$, and of 18.36 per cent for the career growing from 1 to 2 SSWC, with a 15 per cent loss on the only pension served by the AGIRC.

On the contrary, in the case of unemployment, the complementary plans can better compensate the loss in pension. It appears that the loss in complementary pensions is less in the case of early retirement $(-0.58$ per cent) than in the case of unemployment $(-0.96$ per cent) for the career at 1.2 GMW. Then, with regard to a continuous career, the loss of total pension in the case of early retirement is less important than on only the basic plan ( -4.3 per cent vs. -5.9 per cent for a career at $1.2 \mathrm{GMW}$, for example; see Table A1).

Thus, the complementary pension of an insured having interrupted his activity is always lower than the pension of an insured with a continuous career. Nevertheless, for the sample cases considered in which inactivity is connected to the education of children, the familial rights entitled by the basic scheme can "compensate" this kind of interruption by allowing the insurance period required and then the full pension rate.

\section{Conclusion}

This article provides a measure of the impact of several career breaks on the pension at retirement. The statutory pension schemes of the private sector employees include 
mechanisms to compensate career set-backs. However, the mechanisms are not sufficient to guarantee the insured to perceive the amounts they would have earned if they had continued to work.

In the theoretical cases studied and under the assumptions relative to these cases, a break in career could appear to be neutral for the insured, who may perceive the same social security pension than he would have with a continuous career. Nevertheless, the situation for which the pensioner receives an equal pension amount when the career is interrupted is only observed in the specific case of inactivity for children's education. This compensation is not necessarily inefficient, as it not only compensates for the direct consequences of the accident, but also the long-run repercussions on the career. It is notably the case with childbirth because mothers having to temporarily interrupt their activities can have difficulties recovering the same level of wages, or a similar growth in wages, when they are back on the labour market.

Besides, we have to keep in mind that these evaluations are carried out on specific cases. Most of the career accidents lasted entire years - except for the case with unemployment spread over the career path. This has a relatively low impact on the AAW because in counterpart, the years with wages included in the pension are not amputated.

Among the various measures authorities could take to correct the negative consequences of career set-backs on pension, one could be to record the wages which would have been perceived without the career break. An easier to implement and less expensive measure would be to consider the allowances perceived during the career break, as is currently contemplated for maternity leave. However, this solution would not systematically give a higher pension as no wage can be less penalising on the AAW than a low wage (including allowances) for persons who have worked fully for less than 25 years. If we lay cost issues aside, these kinds of measures could be considered for career set-backs such as unemployment or illness, where the allowances are linked to contributions. In return, even if it is also technically possible that in a similar way the social income given to inactive people provide pension rights, that would raise questions about the grounds and the aims of the pension system. Finally, if we are looking to minimise the impact of career set-backs on retirees' revenues, the analysis scope has to be broadened in order to take into account other calculation rules and to consider the social protection system as a whole, as well as the labour market.

\section{Acknowledgements}

The authors would like to thank the anonymous referees for their comments. They are grateful to the "Chaire Dauphine-Ensae Groupama" for their support.

\section{References}

Arun, S.V., Arun, T.G. and Borooah, V.K. (2004) 'The effect of career breaks on the working lives of women', Feminist Economics 10(1): 65-84.

Bommier, A., Magnac, T. and Roger, M. (2003) 'Le marché du travail à l'approche de la retraite: entre 1982 et 1999, évolutions et évaluations, Revue Française d'Economie 18(1): 23-82. 
Briard, K. (2007) 'Standard profiles of private-sector employees: An approach based on career classification' [« Profils types des salariés du secteur privé : approche par une classification des carrières »]', Economie et Prévision 180-181: 59-85.

Burricand, C. and Roth, N. (2000) 'Les parcours de fin de carrière des générations 1912-1941: l'impact du cadre institutionnel', Economie et Statistique 335(1): 63-79.

Caussat, L. (1996) 'Retraite et correction des aléas de carrière', Economie et Statistique 291(1): 185-201.

Cloarec, N. (2000) 'Les passages de l'emploi à la retraite', DARES Premières informations et premières synthèses $n^{\circ} 05.1$.

Colin, C., Iélhé, V. and Mahieu, R. (2000) 'Les trajectoires de fin de carrière des salariés du secteur privé', Dossiers Solidarité et Santé, 3: 9-27 DREES.

Colin, C. and Mette, C. (2003) 'Impact of career setbacks on retirement pensions: Inactivity, unemployment, part-time work and early retirement' [ Impact des différents aléas de carrière sur les retraites: inactivité, chômage, travail à temps partiel et préretraite »], CNAV, Retraite et Société 40: 24-51.

COR (2007) Augmenter le taux d'emploi des seniors: les enseignements des expériences étrangères, Conference report, November.

El Mekkaoui de Freitas, N., Duc, C., Briard, K., Legendre, B. and Mage, S. (2008) Aléas de carrière, inégalités et retraite, Research report $\mathrm{n}^{\circ} 47$ (June), Centre d'Etudes de l'Emploi.

Gupta, N.D. and Smith, N. (2002) 'Children and career interruptions: The family gap in Denmark', Economica 69: 609-629.

Magnac, T., Rapoport and Roger, M. (2006) 'Fins de carrière et départs à la retraite: L'apport des modèles de durée', Dossiers Solidarité et Santé n³, DREES.

Malo, M.A. and Muñoz-Bullon, F. (2008) 'Women's family-related career breaks: A long-term British perspective', Review of Economics of the Household 6(2): 127-167.

Nakamura, J. and Ueda, A. (1999) 'On the determinants of career interruption by childbirth among married women in Japan', Journal of the Japanese and International Economies 13(1): 73-89.

\section{About the Authors}

Sabine Mage is Associate Professor of Economics at the University Paris Dauphine.

Najat EI Mekkaoui de Freitas is Associate Professor of Economics at the University Paris Dauphine and Associate Researcher at Oxford University (OUCE). She coordinates projects about Savings, Employment and Pension systems in France (Ministry of Social Affairs; Employment Studies Center-CEE, France).

Cindy Duc is Economist at the Directorate of research and economics studies at the Ministry of Social Affairs, France and Associate Researcher at the University Paris Dauphine.

Karine Briard is Economist at the Pension Advisory Council in France.

Berangére Legendre is Assistant Lecturer and Associate Researcher at the University Paris Dauphine. 


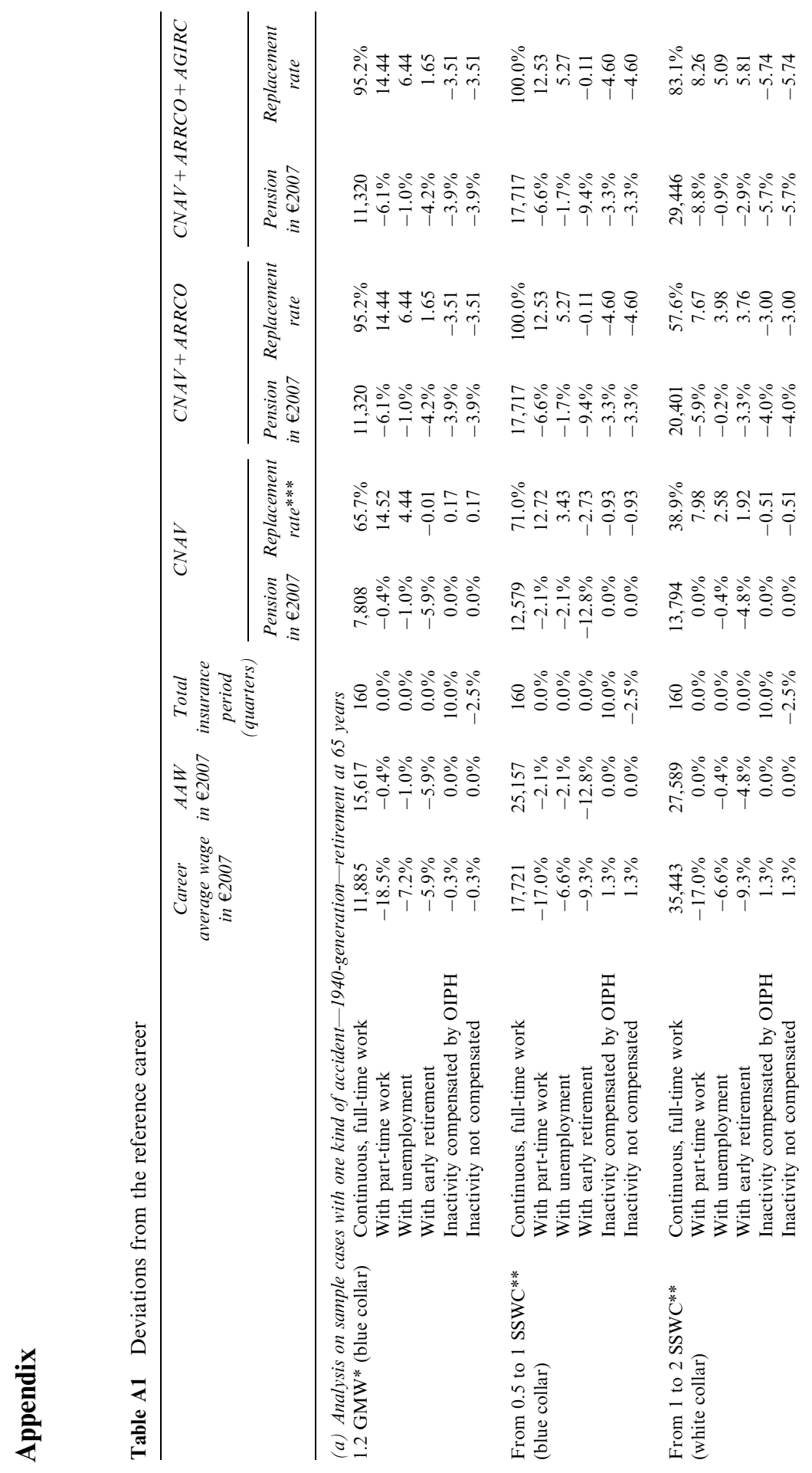




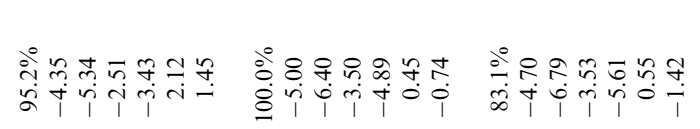

(

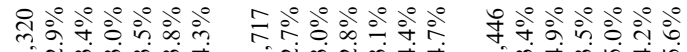

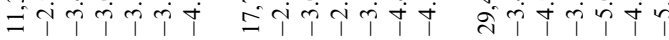

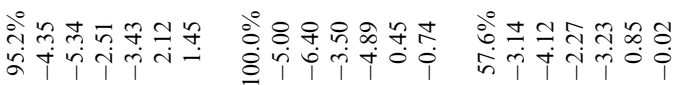

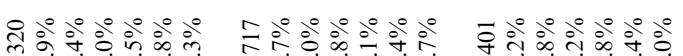

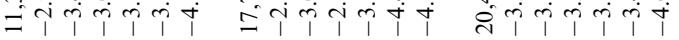

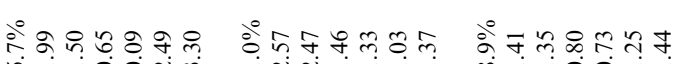
हैं।

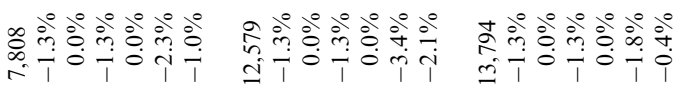

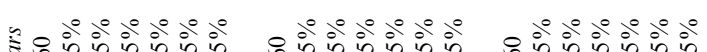

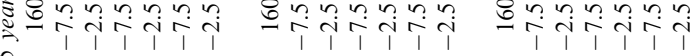
is

‡

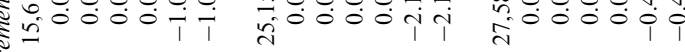

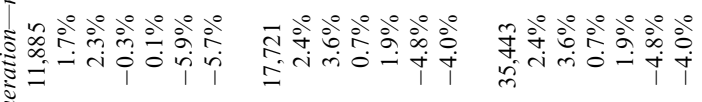
$\frac{9}{8}$

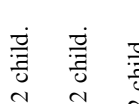

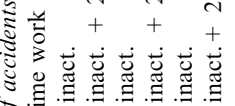

- 方市市方市市

焉正的的的的

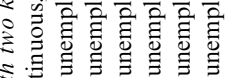

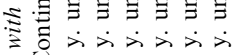
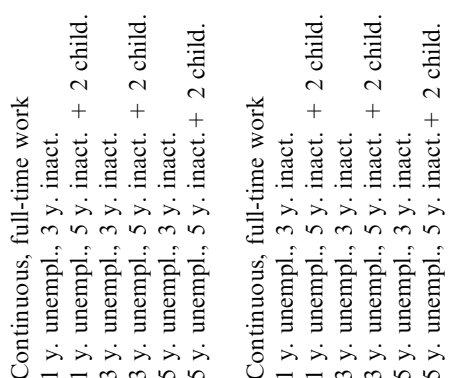

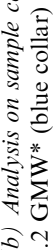
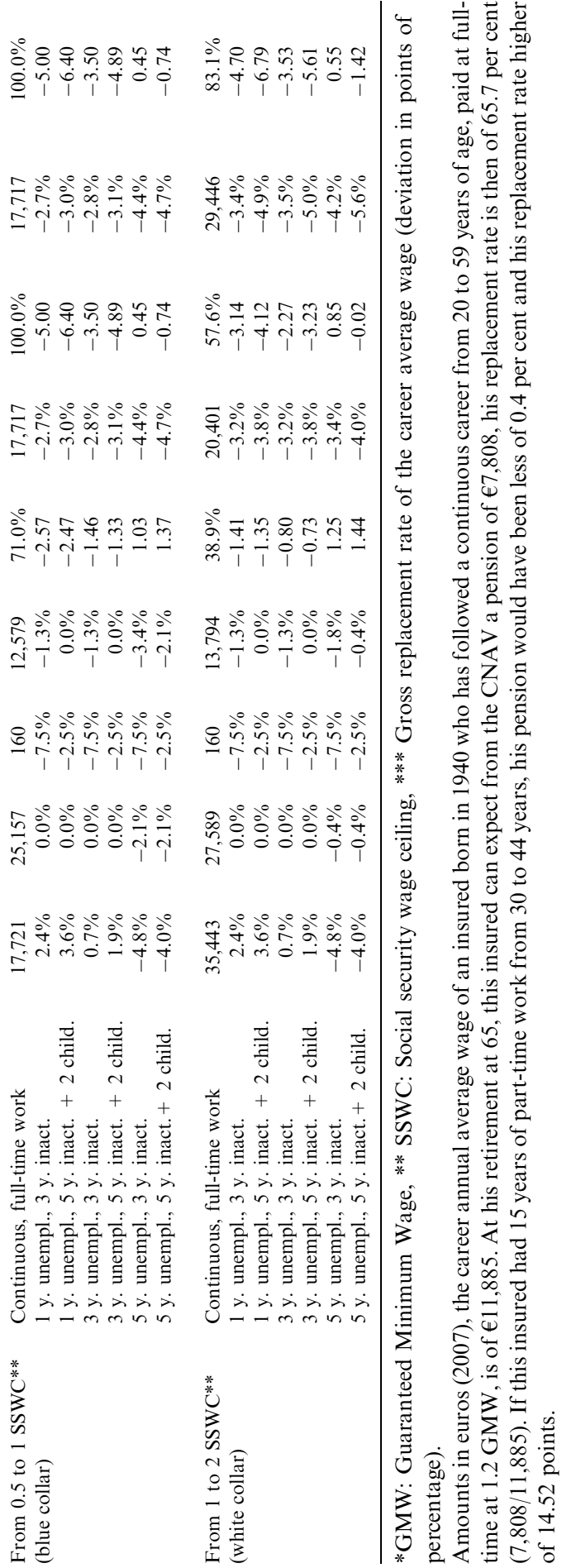
Table A2 Ratio AAW/gross annual wage average (retirement at 65)

\begin{tabular}{|c|c|c|c|c|c|}
\hline \multirow[t]{2}{*}{ Career at 1.2 GMW (blue collar) } & \multicolumn{5}{|c|}{ Generations } \\
\hline & 1940 & 1950 & 1960 & 1970 & 1980 \\
\hline Continuous full-time work & 1.31 & 1.13 & 1.11 & 1.13 & 1.13 \\
\hline With part-time work & 1.60 & 1.29 & 1.26 & 1.26 & 1.26 \\
\hline With unemployment & 1.40 & 1.19 & 1.16 & 1.17 & 1.26 \\
\hline With early retirement & 1.31 & 1.10 & 1.07 & 1.08 & 1.09 \\
\hline Inactivity compensated by OIPH & 1.32 & 1.12 & 1.09 & 1.10 & 1.10 \\
\hline Inactivity not compensated & 1.32 & 1.12 & 1.09 & 1.10 & 1.10 \\
\hline
\end{tabular}

For an insured born in 1940, the annual average wage (AAW) considered for the calculation of his pension is based on his 17 highest actualised wages. Because of the limitation to the best wage, if the insured has followed a continuous full-time career, with wages at $1.2 \mathrm{GMW}$, the AAW is also higher than 31 per cent of the gross annual wage average. From the 1948 generation, the number of wages considered in the AAW goes to 25 , which leads to a decrease of the ratio AAW/gross annual wage average. The variations between the successive generations submitted to the same rules of calculation (here the 1950, 1960, 1970, 1980 generations) are only due to different wage sequences.

\section{Calculation of the social security pension}

Social security pensions are managed by the French national old age insurance fund.

In 2008, the pension was calculated in reference to a continuous 40-year career path paid at the level of $800 \mathrm{~h}$ of GMW per year. Thus, a quarter of insurance is validated for every slice of annual wage at $200 \mathrm{~h}$ of GMW (€1,772 on 1 January 2010). This validation does not take into account the actual duration of activity, so an individual having worked at this rate a single hour a year for 40 years validates 40 years of contribution.

Some non-working periods validate quarters without contributory counterpart. These so-called "assimilated periods", or AP, are granted for any period of 50 days of unemployment, 60 daily allowances in case of disease (also in case of childbirth or of occupational accident) and for any quarterly payment of the invalidity pension.

The social security pension is the product of three terms, in a nutshell:

- the annual average wage (AAW), calculated as the average of the actualised highest annual wages (the 17 highest for the 1940 generation, the 25 highest from the 1948 generation);

- the prorate coefficient, which is the ratio between the insurance period validated by the individual at the Social security scheme, $p_{S S}$, and the statutory maximal insurance period, $P_{S S}(150$ quarters for the 1940-generation until 2008, 160 since);

- the calculation rate $(\tau)$, called "full rate" at its maximum of 50 per cent and reduced by a rate $\delta$ according to the insurance period required to reach 65 years of age or a statutory insurance period, all basic plans being considered, $P_{A P}$ (157 quarters for the 1940 generation until 2003,160 since). 
At retirement, the basic amount of the pension benefit $\mathrm{B}$ is calculated as:

$$
A A W \times \min \left(1, \frac{p_{S S}}{P_{S S}}\right) \times \tau
$$

with $\tau=50 \%-\delta \times \min \left[4 \times(65-a g e), \max \left(0, P_{A P}-p_{A P}\right)\right]$.

For people who are eligible for the full rate, this amount is compared to a minimal amount called "contributory minimum", which is delivered on the prorata of the contribution period validated at the CNAV. On 1 April 2010, its complete annual amount (when $p_{S S} \geqslant P_{S S}$ ) is $€ 7,147.68$.

The complete and full pension is a reference, but is not an average. It rather constitutes an eligible maximum because an insured individual whose career path has ended cannot expect a higher pension or an earlier retirement, except if he benefits from two conditions introduced in 2003: a "surcote", which increases the pension of a rate up to 5 per cent on the condition of pursuing a salaried activity after 60 and being eligible for the full rate; an early retirement, starting at age 56 for the insured having long careers (with conditions of total insurance period, contribution duration and age at the beginning of activity).

Consequently, among the main differences with regard to the continuous career path, we can mention: the losses of rights due to periods of interrupted or reduced activity, and early retirements before eligibility for the full rate with an insufficient contribution duration. 